K A N D A I

\begin{tabular}{|l|l|l|}
\hline Volume 17 & No. 2, November 2021 & Halaman 153-165 \\
\hline
\end{tabular}

\title{
INTERNET SLANG CONTAINING CODE-MIXING OF ENGLISH AND INDONESIAN USED BY MILLENNIALS ON TWITTER \\ (Slang Internet Mengandung Campur-Kode Bahasa Inggris dan Indonesia yang Digunakan oleh Milenial di Twitter)
}

\author{
Adani Nur Sabrina \\ English Department, Faculty of Letters and Cultures, Gunadarma University \\ Jl. Margonda Raya No.100, Depok, Jawa Barat, Indonesia \\ Pos-el: adaninursabrina@staff.gunadarma.ac.id
}

(Diterima: 15 Februari 2021; Direvisi: 3 April 2021; Disetujui: 18 Agustus 2021)

\begin{abstract}
Abstrak
Penelitian ini membahas kreasi slang internet yang mengandung campur-kode bahasa Inggris dan bahasa Indonesia yang dilakukan oleh pengguna milenial Twitter. Tujuan dari penelitian ini adalah untuk mengeksplorasi kreasi slang internet yang menerapkan campurkode bahasa Indonesia dan bahasa Inggris, serta alasan yang memotivasi penggunanya untuk melakukan itu. Metode yang digunakan dalam penelitian ini adalah metode kualitatif yang berarti data yang terkumpul dianalisis dengan penjelasan menggunakan kata-kata. Hasil penelitian menunjukkan terdapat sepuluh kreasi campur-kode yang ditemukan pada tingkatan morfem, tujuh pada tingkatan frasa, dan enam lainnya dalam bentuk singkatan. Penelitian ini juga menemukan bahwa pengguna milenial membuat kreasi slang internet hanya untuk bersenang-senang dan agar percakapan antar sesama pengguna tidak terlalu canggung, kaku, dan formal.
\end{abstract}

Kata-kata kunci: campur-kode, media sosial, milenal, slang internet

Abstract

This research discusses the creation of internet slang which contains the code-mixing of English and Indonesian made by Twitter millennial users. The purposes of this research are to explore those creations of internet slang that implement the Indonesian-English codemixing, as well as the reasons that motivate the users to do so. The method used in this research is a qualitative method which means the collected data are analyzed with explanation in words. The result of the research shows there are ten creations of codemixing found on morpheme level, seven on phrase level, and six other in the form of abbreviation. This research also finds that millennial users create internet slang merely for fun and to make the conversations between fellow users less awkward, stiff, and formal.

Keywords: code-mixing, internet slang, millennials, social media

DOI: $10.26499 / j k . v 17 i 2.3422$

How to cite: Sabrina, A. N. (2021). Internet slang containing code-mixing of English and Indonesian used by millennials on twitter. Kandai, 17(2), 153-165 (DOI: 10.26499/jk.v17i2.3422)

\section{INTRODUCTION}

With the progression of time, the advancement of technology takes a role in complementing the life of society. Varieties of technology have sprung up and one form which is widely used-and seems inseparable from people's daily activities-is social media. Unlike television or radio which function to broadcast mostly in one way, social media act as interactive platforms that provide services for the users to not only share the news but also actively 
participate (Manning, 2014). O'Reilly in Trottier and Fuchs (2014) stated that social media is a place of "a community of connected users"; therefore, people who were previously only able to receive the news, now can share their thoughts and opinions, give feedback, or solely have a chat with friends and family, even make new friends.

The results of the survey on the popularity of social media platforms in Indonesia, analyzed since June 2020 on Statista page (www.statista.com, n.d.-b), show that Facebook is the most frequently accessed platform (89\%), followed by YouTube (83\%), Instagram (79\%), Twitter (34\%), and TikTok $(24 \%)$.

The source of this research focuses on the microblogging platform i.e. Twitter in which the users' posts are in the form of a short text containing up to 280 characters which are called tweets. If the users want to make longer posts, Twitter now also provides a thread feature which is a series of connected tweets, thus the users can post their complete thoughts without being limited by characters.

In Indonesia, as recorded by the survey on Statista page (www.statista.com, n.d.-a), the most social media users are those of age 25 34 years with the total percentage of $35,4 \%$. The online Oxford Learner's Dictionary defines Gen $Y$ as

The group of people who were born between the late 1990s and the early 2010s, who are regarded as being very familiar with the internet. (Oxford Learner's Dictionary, n.d.)

From the definition above, it can be concluded that the average users of social media in Indonesia are Gen Y, also known as millennials. Based on the survey, this research specifically discusses the Twitter users who are categorized as millennials as the most social-media users.

As a tech-savvy generation, the use of language by Indonesian millennials is inevitably affected by globalization. Most of them have the ability to speak not only Indonesian but also the global language, English - regardless of their level of fluency. This bilingualism phenomenon occurs on Twitter timeline frequently. The millennial users oftentimes insert pieces of another language while they are communicating in Indonesian. These inserted pieces of another language, in this context is English, are commonly found in the form of words, but they can also be in the form of phrases or other language units which is called the codemixing phenomenon (Rasul, 2013).

In addition, Offiong and Okon (2013) cited Wardaugh that code-mixing is a source of pride to bilinguals. Codemixing can be viewed as a solidarity marker, and instead of showing laziness or ignorance, the ability to do codemixing requires the insight of the grammar of the two languages as well as societal norms that apply. This means the millennial Twitter users did not create the slang carelessly. They already have the idea in mind on how to combine the two languages to make a term that can be used to express their intention.

Even though slangs are new creations, they are usually easily understood by the first hearing or reading. Figuring out the meaning of the term by comprehending the pattern formation is also found pleasurable. One example that is commonly used is kids zaman now, or other examples such as berprice, penachievean, and so forth. At first glance, Indonesian users who also know English will automatically understand the meaning of the term. However, some slangs are unidentifiable 
that people need to do some internetsurfing or even ask a question to understand the meaning, e.g. $J B$. This slang frequently appears in the Twitter timeline, but some users were found asking the meaning of the term to the user who wrote it. This happens because $J B$ is an acronym and not as clear as words or phrases.

As a matter of fact, slangs are initially used only by a group of people or a community (Batmang \& Gunawan, 2020; Mahendra, 2017; Purba et al., 2019) in this case is Twitter users, but when the usage of slangs has gone beyond that particular circle, they can be found not only on Twitter or any other social media platforms but also face-toface.

Albeit previous researches have discussed slang, they focused on one language of slang. This research is aimed at exploring the creations of internet slang that implement the IndonesianEnglish code-mixing, as well as the reasons that motivate the users to do so; therefore, this research can provide new information related to slang creations, how they are formed, and why they are created.

\section{THEORETICAL FRAMEWORK}

Mayfield (2014) stated there are at least seven kinds of social media: 1) Social Networks, this media allows users to make their own web or profile page and connect to their friends or other users to share their preferred contents. The biggest platform of social networks is Facebook. 2) Blogs, this platform is commonly used as an online journal for any necessities such as personal usage, business usage, or political usage. 3) Wikis, this site is a communal document or database which allows internet users to edit or create content. Wikipedia is an example of this kind.
4) Podcasts, this is a subscription media in the forms of audio and video like what Apple iTunes offers. 5) Forums, this platform is a place to hold an online discussion for its users about particular topics or interests. 6) Content Communities, this media is somehow similar to social networks, but it focuses on organizing and sharing content, whether in the forms of photos (Flickr or Pinterest), videos (YouTube), or both (Instagram). 7) Microblogging, this platform is basically a combination of social networks and a mini version of a blog. Twitter is the vanguard of this kind. Nevertheless, Mayfield believes there will be more innovative developments in terms of social media, thus the emergence of new or combination of social media is not impossible.

We have seen that most social media users are millennials and they are fond of using slang words. Coleman (2012) suggested that slang is a form of language which has emotion in it. Many people like the usage very much that they make sure to always update any terms and use it when they have chances. On the other hand, some people loathe it and tend to look down on people who use it. She also stated in spite of the polarization, there is an argument that slang is creative, vibrant, poetic, and revolutionary. There are various characteristics of slang as stated by Spears (2007), some of them include

1. Much of slang vocabulary is seen as fun both to be heard or to be used.

2. Some slang terms are merely paraphrases of existing terms with the same meaning.

3. Several slang expressions are wordplay and used to entertain people.

4. Slangs can be ephemeral within the groups that created it, but those slangs 
can also live longer if they become general slang.

Bhatia and Ritchie in Kim (2006) stated that code-mixing is the mixing of various linguistic units including morphemes, words, modifiers, phrases, clauses, and sentences primarily from two participating grammatical systems within a sentence.

Meanwhile, Muysken (2000) referred code-mixing to the situation where either lexical items or grammatical features from different languages are used in one sentence. $\mathrm{He}$ suggested three kinds of code-mixing:

1) Insertion

This kind of code-mixing happens when any foreign lexical or phrasal category is put in a sentence of the base language. The language units that can be inserted may vary from different languages. They can be phrases, nouns, or a combination of parts of speech.

2) Alternation

This type occurs between structures from languages which means the interaction between the two languages is in the form of clauses. This type is sometimes referred to as codeswitching because it happens at the switch point.

3) Congruent lexicalization

This kind of code-mixing can be found in a sentence in which the two languages share a similar structure; therefore, it can be filled with lexical elements from either language.

Nababan in Ikhsani (2012) mentioned three reasons for codemixing:

1) code-mixing for fun or because they speak in informal situations. This is done to create intimacy between speakers-in this case is Twitter users.

2) the absence of appropriate terms or expressions. Sometimes, it is hard to find the exact word for a certain term or expression, especially if the term is technical. Thus, people choose to use the foreign word in their utterances.

3) to show their language skills. Indonesian youth, as mentioned earlier, are mostly bilinguals. They oftentimes insert any English word in their sentence because they have the language in them.

Ritchie and Bathia (2008) mentioned four factors that determine language choice and mixing:

1) Participant Roles and Relationship

This factor can be done with or without the agreement of the conversing participants. As they quoted from Myers-Scotton (1993), agreement leads to language matching, which in turn reflects the nature of their perceived social relationship.

2) Situational Factors

Another reason why people do codemixing is that some languages are seen as more suited to certain social groups, settings, or topics.

3) Message-Intrinsic Factors

The forms that belong to messageintrinsic factors include quotations, reiteration, topic-comment/relative clauses, hedging, interjections and idioms, and deep-rooted cultural wisdom.

4) Language Attitudes, Dominance, and Security

Language attitudes mean the intensity of code-mixing depends on how the society sees it: positively or negatively. If society considers it positively, it will promote the usage of mixing languages. Dominance refers to the language proficiency of the speakers. When they forget or even have no clue about the words or expressions they are going to use, they tend to do code-mixing. The last, sometimes when the bilingual 
speakers do not feel secure in using the language, they tend to mix it, for example when they are angry or excited.

\section{RESEARCH METHOD}

This study intends to seek an understanding of a phenomenon; therefore, the researcher uses a qualitative descriptive method. Wijaya (2018) cited Hatch and Anderson that this method is used when the data of the research are descriptive i.e. written or spoken utterances or any behavior that can be observed.

Robson et al. (2001) described some methods to gather qualitative information: 1) interviews and focus groups; 2) questionnaires; 3) observations; 4) document analysis. This study combines two informationgathering techniques i.e. using questionnaires and document analysis. The documents analyzed are tweets containing Indonesian and English codemixing creations which are taken randomly without the users' knowledge in order to maintain the naturalness. As privacy protection, the researcher blurred the username and the profile picture of the users whose tweet is used as an example. Meanwhile, the questionnaire is used as a verification instrument to obtain answers to the reasons why Twitter users took this action. There were 14 participants who took the questionnaire whose age is in between 18-34 years as this research focuses on millennial users. They also have a Twitter account whether they actively use it or not. The questions will be as follows:

1. Are you familiar with these slang words: kids zaman now, akhlakless, negara berflowers, etc.?
2. Have you ever used at least one of those slang words which combine Indonesian and English?

3. Why do you use those words (if you use them)?

4. What is your opinion about this phenomenon?

In order to find out what motivates Twitter millennial users to do such codemixing, the researcher uses the suggestions from Nababan in Ikhasni (2012) and Ritchie and Bathia (2008).

This research uses Twitter (www.twitter.com, n.d.) as its source of data. This platform is chosen because it allows the researcher to look for words or phrases by typing them in the search field without using hashtags.

The data collected are in the form of tweets. They are taken by purposive random sampling on the Twitter platform. Purposive in this research means that the data chosen are those which include the creation of internet slang that contain the Indonesian and English code-mixing, while random here means that each datum has a chance to be chosen.

The procedure of this research will be as follows:

1. Observing Twitter timeline thoroughly to make the researcher aware of the existence of internet slang creations.

2. Taking notes on every creation made by users.

3. Categorizing the data into different levels: morpheme, phrase, and abbreviation.

4. Analyzing the data by providing examples of tweets containing of the creation based on its level, then elucidating the formation as well as the usage of the creation. 


\section{DISCUSSION}

As youngsters, Indonesian millennials tend to use informal ways when communicating with their fellow Twitter users. Since they were born when globalization has influenced their life, they mostly speak both their national language (Indonesian) and the global language (English). This bilingual characteristic allows them to make the informal way of communicating even more fun by creating unique slang terms that they use when expressing opinions, responding to speech, or making comments with other fellow users. This results in a new model of slang. Slang that was previously formed only in one language is now consisting of two languages i.e. Indonesian and English.

The data which are creations of these new internet slang words take place at several levels of language units: morphemes, phrases, and abbreviations (Muysken, 2000; Rasul, 2013; Ritchie \& Bhatia, 2008).

\section{Code-Mixing on Morpheme Level}

During the research, ten code-mixing creations were found on morpheme level.

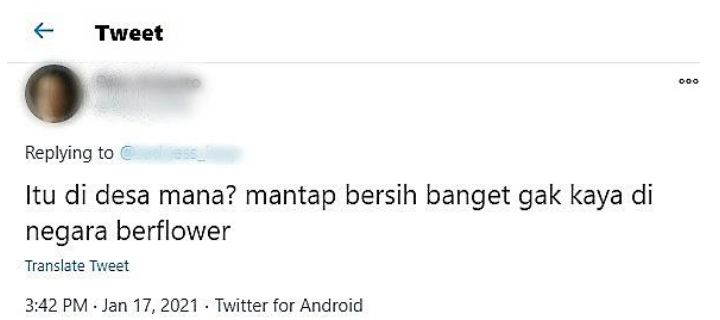

Picture 1. A tweet containing the word "berflower"

Table 1

Code-Mixing on Morpheme Level

\begin{tabular}{l|l}
\hline $\begin{array}{c}\text { Internet } \\
\text { Language } \\
\text { Creation }\end{array}$ & \multicolumn{1}{c}{$\begin{array}{c}\text { Code-Mixing } \\
\text { Elements }\end{array}$} \\
\hline Unfaedah & Un- (E) + faedah $(\mathrm{I})$ \\
\hline Berflower & Ber $-(\mathrm{I})+$ flower $(\mathrm{E})$ \\
\hline
\end{tabular}

\begin{tabular}{l|l}
\hline Sefruit & Se- (I) + fruit (E) \\
\hline Akhlakless & Akhlak (I) + -less (E) \\
\hline Wkwkland & Wkwk (I) + land (E) \\
\hline Penachievean & $\begin{array}{l}\text { Pen- (I) + achieve (E) + } \\
\text {-an (I) }\end{array}$ \\
\hline Berprice & Ber $-(\mathrm{I})+$ price (E) \\
\hline Jujurly & Jujur $(\mathrm{I})+$-ly (E) \\
\hline Tercloud & Ter + cloud \\
\hline Tabokable & Tabok + -able \\
\hline
\end{tabular}

Unfaedah literally means "unimportant" or "useless". This word is created by combining the English morpheme un-which is a negative prefix and the Indonesian word faedah which actually means $a$ benefit, thus if the two are combined, it becomes unimportant or useless because the thing that is unfaedah will not give any benefits. This proves one of slang characteristics stated by Spears (2007) i.e. a paraphrase of a term which has the same meaning. Twitter users created this word simply to make the conversation fun as well as to show their language skills (Nababan, 2012). Another factor is situational as suggested by Ritchie and Bathia (2008) for the conversation takes place on Twitter whose setting is informal and the members usually share the same jokes.

Berflower is a combination of the Indonesian morpheme ber- and the English word flower. Customarily, this slang word is juxtaposed with the word negara (country), so it becomes negara berflower which implies the meaning of "developing country" - in this context is Indonesia. The users created this word because the Indonesian equivalent of developing is berkembang. Berkembang consists of morpheme ber-and kembang. In Indonesian, kembang has another meaning-flower. Thus, the millennial users deliberately choose the wrong diction flower to make it humorous. This is in line with the first reason of codemixing by Nababan i.e. for fun and the situational factors by Ritchie and Bathia (2008). 
Sefruit consists of Indonesian prefix se- and English word fruit. The meaning of this word is actually "one piece" in English. The Indonesian user created such a word because the actual Indonesian word is sebuah which has the morpheme se- and buah. Buah in this context functions as a classifier, but that word also has another meaning that is part of a plant that comes from a flower or pistil (usually with seeds) or in English is called fruit. Thus, they deliberately chose the wrong definition and put it together with the prefix se- to make it fun (Nababan in Ikhsani, 2012) and to match the informal situation on Twitter (Ritchie and Bathia, 2008).

Akhlakless literally means "immoral". The word is formed by combining the Indonesian word akhlak which means moral, and the English suffix -less. This word is used when users want to tell that someone is having a bad manner. The users created this slang also for fun (Nababan in Ikhsani, 2012) and the form is shorter than the real Indonesian phrase tidak berakhlak.

Wkwkland is a word formed by combining Indonesian wkwk and English word land. Wkwk is known as Indonesian e-laughter, meaning when Indonesian users want to express their laughter, instead of haha, they type it with wkwk. Just like other countries which have their own e-laughter such as Japan with their $w w w w$, Thailand with 5555 , or Korea with $k k k k$. The word land here means country or region; therefore, when wkwk and land are put together, they create a new word which means a country whose people's e-laughter is $w k w k$, that is Indonesia. This is done because it is a funnier way to represent the users' country (Nababan in Ikhsani, 2012) and because they know the other users will also understand the meaning behind it (Ritchie and Bathia, 2008).
Penachievean is another way of saying "achievement". In Indonesian, the equivalent of achievement is pencapaian. The Twitter users then combined both words by inserting the English word achieve in between the Indonesian affixes pen- and -an. Just as the previous slang words, the users made this term just for fun and to make the conversation sound friendly (Nababan in Ikhsani, 2012; Ritchie and Bathia, 2008).

Berprice has the same pattern as berflower. It is an insertion kind of codemixing (Muysken, 2000) for it combines the Indonesian morpheme ber- and the English word price. Berprice actually means "valuable". However, in Indonesian, berprice consists of prefix ber-and the word harga. Harga can also mean price in English, so the users choose the wrong diction to make the word fun (Nababan in Ikhsani, 2012).

Jujurly consists of the Indonesian word jujur and the English suffix $-\mathrm{ly}$. This is just a different way of saying honestly since the Indonesian equivalent of "honest" is jujur (Spears, 2007). The users created this word also for fun and because the situation is casual (Nababan in Ikhsani, 2012; Ritchie and Bathia, 200).

Tercloud word became a trend since COVID-19 pandemic attacked Indonesia in 2020. At this time, the serving minister of health is Terawan Agus Putranto. Because his position was closely related to this pandemic, his name was often mentioned in various media and his performance did not go unnoticed. It turned out, some Twitter users were slightly unsatisfied and they started to publish tweets about the minister. Instead of using his real name "Terawan", the users created a new nickname. Although the name is not a word, in Indonesian, it can be split into prefix ter-and awan. Awan means cloud in English, therefore the users inserted 
the English word "cloud" to replace awan, then it became tercloud. This code-mixing is done just for fun as stated by Nababan (in Ikhsani, 2012).

\section{Code-Mixing on Phrase Level}

There are seven kinds of internet slang creations that apply code-mixing in the form of phrases found.

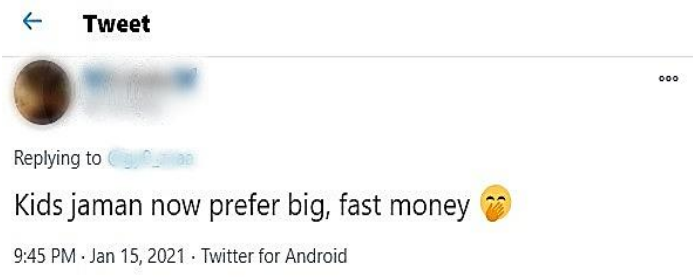

Picture 2. A Tweet Containing the Phrase Kids Zaman Now

Table 2

Code-Mixing on Phrase Level

\begin{tabular}{|c|c|}
\hline $\begin{array}{c}\text { Internet } \\
\text { Language } \\
\text { Creations } \\
\end{array}$ & $\begin{array}{l}\text { Code-Mixing } \\
\text { Elements }\end{array}$ \\
\hline Kids zaman now & $\begin{array}{l}\text { Kids }(\mathrm{E})+\text { zaman }(\mathrm{I})+ \\
\text { now }(\mathrm{E})\end{array}$ \\
\hline $\begin{array}{l}\text { Enggak habis } \\
\text { thinking }\end{array}$ & $\begin{array}{lll}\begin{array}{l}\text { Enggak habis } \\
\text { thinking }(\mathrm{I})\end{array} & + \\
\end{array}$ \\
\hline Sering happening & $\begin{array}{l}\text { Sering (I) + happening } \\
\text { (E) }\end{array}$ \\
\hline No debat & No $(\mathrm{E})+\operatorname{debat}(\mathrm{I})$ \\
\hline $\begin{array}{l}\text { (any Indonesian } \\
\text { verb, noun, or } \\
\text { adjective) online }\end{array}$ & $\begin{array}{ll}\begin{array}{l}\text { Indonesian verb) } \\
\text { online }\end{array} & +\end{array}$ \\
\hline Join bareng & Join $(\mathrm{E})+$ bareng $(\mathrm{I})$ \\
\hline Mantap soul & $\operatorname{Mantap}(\mathrm{I})+\operatorname{soul}(\mathrm{E})$ \\
\hline
\end{tabular}

Kids zaman now is a phrase containing two English words kids and now, and an insertion of Indonesian word zaman (Muysken, 2000). This phrase literally means "the nowadays kids" which refers to the Indonesian youth or millennials themselves. The actual Indonesian phrase is anak-anak zaman sekarang. Kids is the English equivalent of the Indonesian words anak-anak, and now is the equivalent of sekarang. The phrase is usually used when the user wants to show the attitude of the Indonesian millennials. The users created this phrase for fun and so the conversation among them will not sound too formal (Nababan in Ikhsani, 2012; Ritchie and Bathia, 2008).

Enggak habis thinking is a creation formed by combining the Indonesian words enggak habis and the English word thinking. The word thinking there is deliberately used by the user to substitute its Indonesian equivalent pikir, so what should actually be enggak habis pikir is changed into enggak habis thinking. This phrase literally means "unfathomable" in English. We can see that this phrase applies the insertion kind of Kim's codemixing (2007) and Nababan's first reason of code-mixing - for fun (2012).

Sering happening is a phrase containing the combination of the Indonesian word sering and the English word happening. Instead of using the full Indonesian phrase sering terjadi, Twitter users change the Indonesian word terjadi with its English equivalent happening. This phrase actually means that a situation or condition regularly happens. This phrase is created for fun and to make the situation sounds friendly (Nababan in Ikhsani, 2012; Ritchie and Bathia, 2008).

The next phrase is no debat which is the combination of the English word no and the Indonesian word debat. Debat is the equivalence of debate, thus the phrase is used when the users do not want to have any debate with anyone about their statement. This phrase is created by inserting the English word no in the Indonesian sentence written by the Indonesian Twitter millennial users. By saying this phrase, they intend to give a little fun when the situation is potential enough to trigger debates (Nababan in Ikhsani, 2012; Ritchie and Bathia, 2008). 
When Indonesian users want to express their activity, situation, or feeling on Twitter, sometimes they use a combination of any Indonesian verb, noun, or adjective followed by the English word online which means all of their activity/situation/feeling occur virtually. Especially since the COVID19 disease broke out, almost all activities or events are held online. For example:

-ngakak online is a code-mixing which combine the Indonesian verb ngakak and the English word online. Ngakak means "laughing out loud" in English. In addition, since the users cannot really see the other users, some of them show it by typing that they laugh when they read a particular tweet.

-upacara online consists of the Indonesian noun upacara and the English word online. As stated earlier, the pandemic has made many things go virtual including upacara or "ceremony". Therefore, to show that they still do the ceremony-in this case usually is the flag-raising ceremonythe Twitter users write such tweet to inform their readers.

-laper online is a combination of the Indonesian adjective laper and the English word online. Laper is the informal spelling of lapar in Indonesian which means hungry in English. This is just another example of how Twitter users show their unseen feeling or situation to the readers.

All those Indonesian verbs/nouns/ adjectives combined by the English word "online" are merely used for fun and situational because the virtual life limits the real visual meetings so that the users feel the necessity to describe what they feel or do to their fellow Twitter users (Nababan in Ikhsani, 2012; Ritchie and Bathia, 2008).

Join bareng is a phrase that consists of the English word join and the Indonesian word bareng. This expression literally means join together. This phrase is often used by millennials on Twitter, especially when they try to reply a stranger's tweet and to join the conversation. The users created this phrase because of their bilingual skills (Nababan in Ikhsani, 2012) and also the situational factor (Ritchie and Bathia, 2008).

Mantap soul contains a codemixing of the Indonesian word mantap and the English word soul. Initially, the phrase was made in full Indonesian "mantap jiwa", but the users wanted to make it more interesting by changing the second word into English, since jiwa is the equivalent of soul. Mantap means great in English; therefore, the phrase implies a meaning that something is really great that it touches the soul. This creation applies Nababan's first codemixing reason as it is made for fun (2012), and the situational factor reason from Ritchie and Bathia (2008) which takes form as an insertion kind of codemixing (Kim, 2007).

\section{Code-Mixing in the Form of Abbreviation}

Not only in the form of morphemes or phrases, but millennials also create a mixture of the two languages in the form of abbreviations. At least six creations were found in this form.

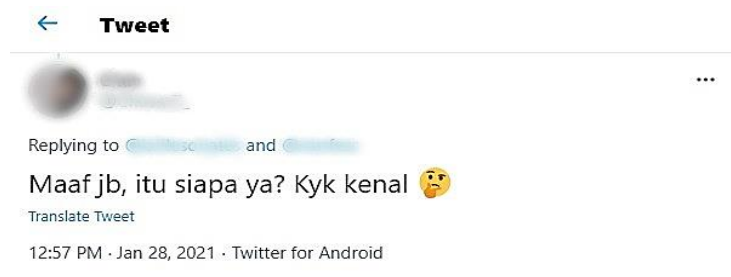

Picture 3. A Tweet Containing the Abbreviation $J B$ 
Table 3

Code-Mixing in the Form of Abbreviation

\begin{tabular}{l|l}
\hline $\begin{array}{c}\text { Internet Language } \\
\text { Creation }\end{array}$ & \multicolumn{1}{|c}{\begin{tabular}{c}
\multicolumn{1}{c}{ Code-Mixing } \\
Elements
\end{tabular}} \\
\hline JB (Join Bareng) & $\begin{array}{l}\text { Join-J (E) + Bareng-B } \\
(\mathrm{I})\end{array}$ \\
\hline $\begin{array}{l}\text { Ntapsoul (Mantap } \\
\text { soul) }\end{array}$ & $\begin{array}{l}\text { Mantap-Ntap(I) + Soul } \\
(\mathrm{E})\end{array}$ \\
\hline Ilfeel (Ilang feeling) & $\begin{array}{l}\text { Ilang-Il (I) + feeling } \\
(\mathrm{E})\end{array}$ \\
\hline $\begin{array}{l}\text { Kudet (kurang } \\
\text { update) }\end{array}$ & $\begin{array}{l}\text { Kurang-Ku (I) + } \\
\text { update-det (E) }\end{array}$ \\
\hline Lola (loading lama) & $\begin{array}{l}\text { Loading-Lo (E) + } \\
\text { Lama-La (I) }\end{array}$ \\
\hline Jaim (Jaga image) & $\begin{array}{l}\text { Jaga-Ja (I) + Image-Im } \\
(\mathrm{E})\end{array}$ \\
\hline
\end{tabular}

$\boldsymbol{J B}$ is an abbreviation of Join Bareng containing the English word Join and the Indonesian word Bareng which literally means join together. This abbreviation is usually used when the users would like to join other users' conversations or tweets who happen to be strangers. $J B$ is hoped to be a bridge and permission so that the users whose tweet is replied to do not feel uncomfortable by the sudden presence of a stranger user. This phrase is created because the users in question have both English and Indonesian language skills so they insert a piece of the foreign language (English) in their Indonesian sentence (Nababan in Ikhsani, 2012; Kim, 2007).

Ntapsoul is the blending of the phrase mantap soul. The phrase mantap soul itself is literally translated into great soul which implies a meaning that a particular thing or situation is superb that the good feeling reaches the soul. It is actually merely the abbreviation form of the previous data from Code-Mixing on Phrase Level. This abbreviation version is sometimes considered funnier (Nababan in Ikhsani, 2012).

Ilfeel is made of the Indonesian word ilang (the informal spelling of hilang) and the English word feeling. This abbreviation is used to indicate that someone has lost feeling or is no longer interested towards someone, because hilang means lose in English. This creation is done because of the situational factors since the setting is casual and the interlocutors are those of the same social group (Ritchie and Bathia, 2008). Another reason is because the creators are able to speak both Indonesian and English, so to make the phrase short, they abbreviate the phrase hilang feeling into ilfeel (Nababan in Ikhsani, 2012).

Kudet is the abbreviation of the Indonesian word kurang and the English word update. Kurang becomes $k u$ and update becomes det because the "update" pronunciation is transcribed as "apdet" in Indonesian. Kurang means "lacking" in English, thus if someone is kudet, it means that he or she is lacking of the new updates or outdated. This creation is made because the users have the English and Indonesian skills and also to make the expression shorter (Nababan in Ikhsani, 2012).

Lola is the abbreviation of the English word loading and the Indonesian word lama. In English, lama is an adjective that means slow or take a long time. When it is combined with loading and is used to describe someone, it means that the person has a slow thinking process just like a computer that keeps loading when it is ordered to do something with its system. This creation is made as a fun way to refer to someone and because they have the skills of both languages (Nababan in Ikhsani, 2012). This expression is usually used within the same group and only when the situation is informal (Ritchie and Bathia, 2008).

Jaim abbreviation consists of the Indonesian word jaga and the English word image. Jaga means keep in English, so the expression jaga image means to keep someone's or something's good impression. This abbreviation is 
created because the users have the ability to speak English and Indonesian, then they try to make a shorter form to express the situation (Nababan in Ikhsani, 2012; Ritchie and Bathia, 2008).

\section{Questionnaire Results}

Question 1: Are you familiar with these slang words: kids zaman now, akhlakless, negara berflower, etc.)?

All 14 participants answered that they are familiar with those slang creations.

Question 2: Have you ever used at least one of those slang words which combine Indonesian and English?

Eleven participants stated that they have used the slang words, meanwhile the three of them declared that they have never used any of the slang creations.

Question 3. Why do you use those words (if you use them)?

Eight participants who took the questionnaire said that they use it merely for fun; two of them stated that they are just following the bandwagon and one of the two said that he or she is influenced by his or her alay friends; the other two of participants declared that they do it naturally without specific reasons; the two out of three participants who never use it left the answer column blank, while one of them clarified that he or she does not use the creations because those words are against the language rules.

\section{Question 4: What is your opinion about this phenomenon?}

One participant thinks that this phenomenon is fun, but when it is used excessively, the trend becomes annoying. Another participant stated that these slang terms are good because when he or she uses it with his or her close friends, the conversation will not sound too formal. Another opinion suggested by one other participant is that the trend seemed weird at first, but then he or she has got used to it and considered it as a common thing. A different thought from another participant is this phenomenon is fine as long as it does not ruin the Indonesian language. One other participant declared that this language trend is natural as the time goes by and the youth generation takes part in society with their own creativity. A quite similar view is suggested by another participant that this slang words phenomenon is funny and creative. Still related to creativity, another participant has a notion that in a language point of view, this phenomenon can be used as a means for creativity when communicating and that it is just a language development that often happens in any social classes. Another participant said this is just something that regularly comes and goes. The other stated that these creations are just another way of expressing thoughts. Meanwhile, the other five participants think that there is nothing special with this phenomenon.

The results of the questionnaires show some reasons why Indonesian millennial users like to create such internet slang. Many of these millennials only enliven the Twitter timeline with slang words simply for fun. They also feel that using a mixture of languages is funny and interesting because it shows the wit of Twitter users. However, there is also an argument that the excessive use of these expressions will decrease the excitement and turn annoying.

\section{CONCLUSION}

Based on the data collected, the researcher finds ten creations of codemixing on morpheme level, seven on phrase level, and six other in the form of abbreviation. This shows that the creativity of millennials in making 
internet slang is not limited to a certain level as Bhatia and Ritchie in Kim (2006) stated that code-mixing covers various linguistic units. This also means that the kind of code-mixing creations that are mostly done by Indonesian Twitter millennial users are insertion (Muysken, 2000).

The results of the questionnaire show that many of Indonesian millennials only vivify the Twitter timeline with slang words for fun because it shows the wit of Twitter users. This phenomenon is also carried out in such a way that the conversations which occur between users do not feel awkward, stiff, or too formal. However, there is also an argument that the excessive use of these expressions will decrease the excitement and turn annoying. This means the creations of internet slang containing code-mixing of Indonesian and English are made solely for fun since they use Twitter as a platform to discuss topics in an informal way and also because the users have the skills to communicate in Indonesian and English. This follows the first and the third reasons suggested by Nababan in Ikhsani (2012) and two factors stated by Ritchie and Bathia (2008) i.e. participant roles and relationship, as well as situational factors.

Indubitably, a social phenomenon like this will constantly grow and develop which will result in more and more creations of internet slang that can appear whether in the same levels or in other new forms. In point of fact, the nature of language is dynamic, which means that it grows with the times. The emergence of these kinds of phenomena also livens up the richness of creativity in language as long as it is not excessive and does not diminish the identity of the speakers of the language.

\section{REFERENCES}

Batmang \& Gunawan, F. (2020). Issues of social values in the Arabic teaching of islamic higher education students in Indonesia. Journal of Social Studies Education Research, 11(4), 235256.

Coleman, J. (2012). The life of slang. Oxford University Press.

Fuchs, C., \& Trottier, D. (2014). Theorising social media, politics and the state: An introduction. Social Media, Politics and the State: Protests, Revolutions, Riots, Crime and Policing in the Age of Facebook, Twitter and YouTube, 3-38. https://doi.org/10.4324/97813157 64832

Ikhsani, N. A. (2012). Code mixing in the articles of Gogirl! Magazine February, 2013 Edition. Lexicon, 1(3), 293-304.

Kim, E. (2006). Reasons and motivations for code-mixing and code-switching. Issues in EFL, 4(1), 43-61. http://originalresearch.blog.uns.a c.id/files/2010/04/reasons-andmotivations-for-code-mixingand-code-switching-by-eunheekim.pdf

Mahendra, O. (2017). EnglishIndonesian Slang (Alay): An ethnography study. UAD TEFL International Conference, 1, 421. https://doi.org/10.12928/utic.v1.1 96.2017

Manning, J. (2014). Social media, definition and classes of. Encyclopedia of Social Media and Politics, January. https://doi.org/10.4135/97814522 44723.n485 
Mayfield, A. (2014). What is social media? In M. Cross (Ed.), What is social media? Syngress. https://doi.org/10.1016/b978-159749-986-6.00001-1

Muysken, P. (2000). Bilingual speech: a typology of code-mixing. Cambridge University Press.

Offiong, O. A., \& Okon, B. A. (2013). Of Efik and English: Code mixing. Theory and Practice in Language Studies, 3(5), 728-735. https://doi.org/10.4304/tpls.3.5.7 28-735

Oxford Learner's Dictionary. (n.d.). Retrieved January 14, 2021, from https://www.oxfordlearnersdictio naries.com/definition/english/gen $-y ? q=$ gen $+y$

Purba, A. J. M., Herman, \& Purba, C. N. (2019). An analysis of Indonesian slang words in mojok essay. European exploratory scientific journal vol 3 (3), 1-8.

Rasul, S. (2013). Borrowing and code mixing in Pakistani children's magazines: Practices and functions. Pakistaniaat: A Journal of Pakistan Studies, 5(2), 46-72.

Ritchie, W. C., \& Bhatia, T. K. (2008). Social and Psychological Factors in Language Mixing. The Handbook of Bilingualism, June 2018, 336-352.
Robson, L. S., Shannon, H. S., Goldenhar, L. M., \& Hale, A. R. (2001). Chapter 7. Qualitative methods for effectiveness of evaluation: When numbers are not enough. In Guide to Evaluating the Effectiveness of Strategies for Preventing Work Injuries: How to Show Whether a Safety Intervention Really Works DEPARTMENT OF HEALTH AND HUMAN SERVICES Public Health Service Centers for Disease Control and Prevention National Inst (p. 68). NIOSH.

Spears, R. A. (2007). McGraw Hill's Dictionary of American Slang and Colloquial Expressions. McGraw Hill.

Wijaya, H. (2018). Analisis data kualitatif model Spradley. Sekolah Tinggi Filsafat Jaffray Makassar, March, 1-9. https://www.researchgate.net/pub lication $/ 323557072$

www.statista.com. (n.d.-a). Breakdown of social media users in Indonesia by age and gender as of 2020. https://www.statista.com/statistic s/997297/indonesia-breakdownsocial-media-users-age-gender/

www.statista.com. (n.d.-b). Leading social media platforms accessed daily in Indonesia. Retrieved January 14, 2021, from https://www.statista.com/statistic s/1168819/indonesia-socialmedia-platforms-used-daily/

www.twitter.com. (n.d.). Twitter. Retrieved February 23, 2021, from www.twitter.com 